\title{
KRITIK SANAD HADIS KHITAN TERHADAP PEREMPUAN SEBAGAI KEHORMATAN
}

\section{CRITICISM OF SANAD HADITH RELATING WOMAN CIRCUMCISION AS HONOR}

\author{
Abdul Rahman Sakka \\ Universitas Islam Negeri (UIN) Alauddin Makassar \\ Email: abdrsakka@gmail.com
}

\section{Keywords :}

sanad, hadith, circumcision, makrūmah, weak

\section{ABSTRACT}

Hadith relating to woman circumcision as honor used as the argument in the MUI fatwa number 9a of 2008 has received a lot of criticisms. Thus, it is important to re-research as a form of followup to the previous research. This research was a research library with critical analytical methods on the hadith sanad with the aim of knowing with certainly the quality and quantity of hadith and its authenticity. Based on the results of the study, it was found that there were ten transmission routes listed by the four mukharrij rulers; that is; Ahmad bin Hanbal, Ibn Abi Syaibah, al-Tabrani, and al-Baihaqi. Of the ten lines of transmission, seven are hadiths marf' $u$ and three lines of hadith mauqu $f$. In terms of quantity ('adad al-turuq), this hadith is classified as a famous hadith because it is narrated by a minimum of four narrators in each sanad tabaqah (level). Meanwhile, in terms of quality, this hadith is defined as a very weak hadith (da'if jiddan) because of the inherent defects involved in the narration. Thus it cannot be used as the main argument to justify circumcision against women and also cannot be used as an argument for woman circumcision for reasons of honor. This hadith can only be a reinforcement of the authentic and hasan traditions which talk about female circumcision. The inclusion of this hadith in the MUI fatwa as the main argument for justifying circumcision for women needs to be reviewed considering that this hadith is very weak..

\section{Kata kunci :}

sanad, hadis, makrūmah, daif.

\section{ABSTRAK}

khitan, Hadis tentang khitan merupakan kehormatan bagi kaum perempuan yang dijadikan dalil dalam fatwa MUI Nomor 9a tahun 2008 telah mendapat banyak kritikan sehingga penting untuk dilakukan penelitian ulang sebagai bentuk tindak lanjut dari penelitian sebelumnya. Penelitian ini merupakan library research dengan metode analisis kritis terhadap sanad hadis dengan tujuan untuk mengetahui dengan pasti kualitas dan kuantitas hadis serta kehujahannya. Berdasarkan hasil penelitian ditemukan ada sepuluh jalur periwayatan yang dicatatkan oleh empat perawi mukharrij; yaitu; Ahmad bin Hanbal, Ibn Abi Syaibah, al-Tabrani, dan alBaihaqi. Dari sepuluh jalur periwayatan tersebut tujuh merupakan jalur hadis marf' $u$ dan dan tiga jalur hadis mauqūf. Secara kuantitas ('adad al-turuq), hadis ini digolongkan hadis masyhur karena diriwayatkan oleh minimal empat perawi di setiap tabaqah (level) sanad. Sedangkan dari sisi kualitas, hadis ini ditetapkan sebagai 


\begin{abstract}
hadis da' îf jiddan (sangat lemah) karena kecacatan perawinya yang terlibat dalam periwayatan. Dengan demikian ia tidak bisa dijadikan dalil utama untuk membenarkan khitan terhadap perempuan dan juga tidak dapat dijadikan hujah bolehnya khitan perempuan karena alasan kehormatan. Hadis ini hanya bisa menjadi penguat terhadap hadis sahih dan hasan yang berbicara tentang khitan bagi perempuan. Pencantuman hadis ini dalam fatwa MUI sebagai dalil utama pembenaran khitan bagi perempuan perlu ditinjau ulang mengingat hadis ini sangat lemah.
\end{abstract}

Diterima: 17 April 2021; Direvisi: 12 Mei 2021; Disetujui: 1 Juni 2021; Tersedia online: 11 Juni 2021

How to cite: Abdul Rahman Sakka. "Kritik Sanad Hadis Khitan Terhadap Perempuan sebagai Kehormatan." NUKHBATUL 'ULUM: Jurnal Bidang Kajian Islam 7, no. 1 (2021): 99-118. https://doi.org/10.36701//nukhbah.v7i1.324.

\section{PENDAHULUAN}

Sejak keluarnya Peraturan Menteri Kesehatan no.6 tahun 2014 tentang Pencabutan Peraturan Menteri Kesehatan nomor 1636/MENKES/PER/XII/2010 tentang sunat perempuan, praktek sunat perempuan menuai polemik dan kontraversi. Kontroversi tersebut baik dari sisi medis, agama, maupun aspek legalitasnya. Hal itu disebabkan oleh karena Majelis Pertimbangan Kesehatan dan Syara'k yang diberi mandat untuk menerbitkan Pedoman Penyelenggaraan Sunat Perempuan sebagaimana dalam pasal 2 permenkes 6/2014 tidak ada tindak lanjutnya. ${ }^{1}$ Preeti Jhe bahkan mengkritik penyerahan mandat tersebut kepada Dewan Kesehatan untuk memberikan Pedoman Female Genital Mutilation (FGM) justru akan secara efektif memperluas dan semakin tidak membatasi praktek khitan tersebut. Ia mengajukan fakta temuan PBB tahun 2016, dimana hampir setengah dari anak perempuan Indonesia berusia 11 tahun ke bawah telah menjalani FGM. Karena itulah ia mengkampanyekan pelarangan dan penghentian FGM dengan alasan resiko kesehatan. ${ }^{2}$ Resiko kesehatan yang ditimbulkan adalah adanya efek negatif seperti kerusakan pada alat kelamin perempuan dan mengganggu fungsi normal organ reproduksinya dan bahkan dapat menimbulkan trauma dan stress psikis pada perempuan yang mengalaminya. ${ }^{3}$ Kampanye penghapusan khitan terhadap perempuan mendapat restu dari WHO sebagai organisasi kesehatan dunia. WHO

1 Bernadetha Aurelia Oktavira, "Legalitas Sunat Perempuan di Indonesia", Hukum Online.com.19 Februari 2020. https://www.hukumonline.com/klinik/detail/lt5004324178331/legalitas-sunat-perempuan-diindonesia/. Diakses pada 17 September 2020.

${ }^{2}$ Preeti Jha, “Southeast Asia's Hidden Female Genital Mutilation Challenge”. The Diplomat, August,21, 2019. https://thediplomat.com/2019/08/southeast-asias-hidden-female-genital-mutilationchallenge/. Diakses pada 17 September 2020.

${ }^{3}$ Mukhammad Zamzami, "Perempuan dan Narasi Kekerasan: Analisis Hukum dan Medis Sirkumsisi Perempuan," Asy-Syir'ah: Jurnal Ilmu Syari'ah Dan Hukum 51 no.1 (Juni 2017): 53, 73. doi.org/10.14421/asy syir'ah.2017.511.53-78 
secara resmi dan tegas menentang praktek khitan perempuan dan menetapkan sebagai pelanggaran terhadap hak-hak perempuan, kesehatan dan intergritas anak perempuan, dan telah mencanangkan tahun 2030 sebagai akhir dari Female Genital Mutilation ${ }^{4}$.

Menyikapi kontroversi dan desakan banyak pihak, Majelis Ulama Indonesia (MUI) sebagai lembaga fatwa resmi Negara, semenjak tahun 2008 telah mengeluarkan fatwa tentang hukum pelarangan khitan terhadap perempuan. Dalam fatwanya nomor 9a tahun 2008 yang terdiri dari empat diktum MUI menetapkan bahwa pelarangan khitan perempuan bertentangan dengan ketentuan syariat karena merupakan fitrah (aturan) dan syiar Islam, bahkan khitan terhadap perempuan adalah maknummah, dan merupakan salah satu bentuk ibadah yang dianjurkan. ${ }^{5}$ Menurut Asrorun Ni'am Sholeh, keluarnya fatwa MUI merupakan respon tegas MUI terhadap gerakan pelarangan khitan bagi perempuan karena dinilai bertentangan dengan ketentuan syariat, tidak sejalan dengan konstitusi, dan bertentangan dengan hak asasi manusia yang paling mendasar yakni hak kebebasan beragama dan menjalankan agamanya. ${ }^{6}$

Alasan mendasar MUI menolak pelarangan khitan terhadap perempuan adalah karena khitan dianggap sebagai maknūmah yang berdimensi ibadah. MUI berdalil dengan hadis riwayat Ahmad berikut;

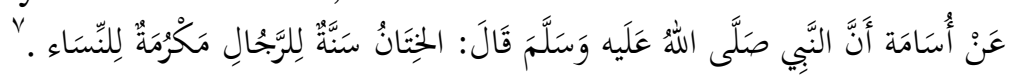

Artinya: Dari Usamah bahwasanya Nabi SAW bersabda khitan merupakan sunah bagi laki-laki dan kehormatan bagi perempuan.

Hadis yang menjadi landasan fatwa MUI ini dipermasalahkan oleh banyak kalangan. Ashabul Fadhli dalam penelitiannya menyebutkan bahwa hadis yang memerintahkan khitan bagi perempuan untuk meraih kehormatan sebagai kecenderungan yang lebih mengarah kepada faktor perilaku, berupa kebiasaan yang menggejala yang pada akhirnya berubah menjadi nilai di tengah masyarakat. ${ }^{8}$ Nurasiah menilai khitan tidak memiliki sandaran teks agama yang kuat karena hanya berdasar pada hadis yang lemah, karena itu kepentingan khitan tidak memiliki keterkaitan secara langsung dengan syariat Islam sebagai suatu perintah yang disunahkan. ${ }^{9}$ Nurma Sayyidah ${ }^{10}$ dan Moh Rosyid ${ }^{11}$ yang meneliti teks hadisnya

\section{${ }^{4}$ United Nations, Ending Female Genital Mutilation by 2030,}

https://www.un.org/en/observances/female-genital-mutilation-day. Diakses pada 4 November 2020

${ }^{5}$ Majelis Ulama Indonesia, "Fatwa Majelis Ulama Indonesia no. 9a tahun 2008 tentang Hukum Pelarangan Khitan Terhadap Perempuan”. http://mui.or.id/wp-content/uploads/files/fatwa/29.Hukum-Pelarangan-Khitan-Terhadap-Perempuan.pdf. Diakses pada 17 September 2020

${ }^{6}$ M. Asrorun Ni'am Sholeh, "Fatwa MUI Tentang Khitan Perempuan," AHKAM : Jurnal Ilmu Syariah XII, no. 2 (Juli 2012): 44 https://doi.org/10.15408/ajis.v12i2.964. 35-46

${ }^{7}$ Abu Abdillah Ahmad bin Muhammad bin Hanbal bin Hilal bin Asad al-Syaibani (164-241 H), Musnad Ahmad bin al-Hanbal, no. hadis 20719, Jilid 34 Cet. I (Beirut: Mu'assasah al-Risālah, 1994), h. 319.

8 Ashabul Fadhli, "Meramu Ketentuan Hukum Islam Terkait Khitan Perempuan," JURIS (Jurnal Ilmiah Syariah) 14, no. 1 (2016): 59, https://doi.org/10.31958/juris.v14i1.296. 47-61

${ }^{9}$ Nurasiah, "Khitan Dalam Literatur Hadis Hukum," AHKAM : Jurnal Ilmu Syariah, XV no. 1 (Januari 2019): 93 https://doi.org/10.15408/ajis.v15i1.2851. 81-94 
berkesimpulan sama bahwa hadis yang memberitakan khitan terhadap perempuan sebagai kehormatan yang diriwayatkan Ahmad adalah hadis daif karena seorang perawinya bernama Al-Hajjaj tidak kredibel.

Dari tinjauan beberapa penelitian di atas, tampak ada kesamaan dari sisi penilaian terhadap kedudukan hadis, bahwa hadis khitan terhadap perempuan sebagai kehormatan bukanlah hadis yang kuat yang dapat dijadikan landasan praktek khitan terhadap perempuan karena kecacatan seorang perawinya. Hanya saja, kesimpulan yang diambil tidak berdasarkan data yang akurat dan analisis data yang tajam. Tidak keakuratan datanya karena hanya berdasar pada satu hadis saja yakni hadis riwayat Ahmad bin Hanbal dan tidak menelusuri kemungkinan adanya jalur sanad lain. Analisanya kurang tajam karena perawi cacat yang menjadi penyebab kedaifan hadis tidak dijelaskan sebab kecacatannya, dan juga tidak disertai analisa tingkat kedaifan hadis.

Berdasarkan hal di atas, penelitian ini urgen dilakukan dengan tujuan untuk melengkapi kekurangan penelitian yang sudah ada, dan untuk menguatkan kelemahannya, serta menemukan hal-hal baru yang berbeda dengan sebelumnya dengan cara melakukan kritik sanad secara komprehensif pada seluruh jalur sanad hadis khitan perempuan sebagai suatu kehormatan. Penelitian ini didasarkan pada argumen bahwa sebuah hadis bisa dijadikan hujah dan sandaran hukum agama jika hadis tersebut memiliki kualitas sahih atau hasan dan bukan hadis daif. Sedangkan penentuan kualitas suatu hadis dapat dilakukan jika telah melalui proses kritik sanad secara komprehensif. Penelitian ini merupakan library research (studi pustaka) dengan metode analitis kritis terhadap sanad hadis dengan pendekatan teologinormatif. Dalam kegiatan kritik sanad ditempuh tiga langkah; pertama, melakukan penelusuran hadis ke kitab sumber utamanya melalui metode takhn̄j. Kedua, menghimpun hadis yang telah ditemukan dengan melakukan i'tibār. Ketiga menganalisis kualitas perawi yang terlibat dalam periwayatan hadis dan menganalisis metode yang digunakan dalam periwayatan

\section{PEMBAHASAN}

\section{Kritik Sanad Hadis}

Sanad adalah rentetan perawi hadis yang menghubungkannya hingga sampai kepada matan. ${ }^{12}$ Makna lain adalah mata rantai sejarah yang terdiri dari manusia yang menghubungkan antara pencatat hadis dengan sumber riwayat, yaitu Rasulullah saw pada hadis marfu' atau sahabat pada hadis mauqu$f$ dan pada tabiin pada hadis

\footnotetext{
${ }^{10}$ Nurma Sayyidah, "Hadis Tentang Hukum Khitan Perempuan (Kajian Sanad Dan Matan)," Jurnal Studi Ilmu-Ilmu Al-Qur'an Dan Hadis, 17. no. 1 (Januari 2016): 147, https://doi.org/10.14421/qh.2016.1701-07. 147-160

${ }_{11}$ Moh. Rosyid, "Hadis Khitan Pada Perempuan: Kajian Kritik Matan Sebagai Upaya Mengakhiri Diskriminasi Gender," Riwayah: Jurnal Studi Hadis, 6 No. 1 (2020):36, https://doi.org/10.21043/riwayah.v6i1.6869. 19-38

${ }^{12}$ Mahmud al-Tahhan, Taisīir Muṣtalạ̣ al-Hadis (al-IskanDāriyah: Markaz al-Hady li alDirāsat, 1415 H), h. 18
} 
maqtū ${ }^{\prime 13}$ Sanad memiliki kedudukan yang sangat urgen dalam hadis. Karena menjadi faktor utama yang menentukan keabsahan sebuah hadis. Suatu berita yang dinyatakan berasal dari Nabi saw jika tidak memiliki sanad sama sekali maka berita tersebut oleh para ahli hadis ditolak dan tidak diterima sebagai hadis. ${ }^{14}$ Sebuah ungkapan populer dari Abdullah bin al-Mubarak; "sekiranya tidak ada sanad, maka siapa saja bisa mengatakan apa yang dikehendaki". ${ }^{15}$

Kritik sanad merupakan upaya untuk membedakan sahih dan daifnya suatu hadis, serta menetapkan status perawi yang terlibat dalam suatu rantai periwayatan apakah ia perawi yang terpercaya atau cacat. ${ }^{16}$ Upaya menyingkap keadaan perawi yang lemah dan pendusta dalam suatu rangkaian sanad bersifat wajib demi menjaga (kehormatan) agama. ${ }^{17}$ Menurut Syuhudi Ismail, ulama hadis dalam melakukan penelitian sanad (kritik sanad) lebih fokus pada keadaan para perawi dalam sanad itu saja, padahal sesungguhnya ada dua bagian penting dalam melakukan kritik sanad, yakni; perawi hadis yang terlibat dalam periwayatan hadis yang bersangkutan, dan lambang periwayatan hadis yang digunakan oleh masing-masing perawi dalam meriwayatkan hadis, seperti sami'tu, akhbarani, 'an. ${ }^{18}$

Adapun kritik sanad yang dimaksudkan di sini adalah kegiatan penelitian terhadap perawi yang terlibat dalam periwayatan hadis dari generasi ke generasi dalam suatu mata rantai sanad, dan menganalisis metode periwayatan yang digunakan perawi sehingga dapat ditentukan aspek kuantitas dan kualitasnya.

\section{Takhn̄j al-Hadî́}

Ada beberapa defenisi takhrīj al-ḥadîs yang disebutkan ulama. ${ }^{19}$ Namun takhrīj alhadís yang dimaksudkan dalam penelitian ini adalah upaya pencarian atau penelusuran hadis di berbagai kitab yang merupakan sumber asli dari hadis yang tersebut, yang di dalam sumber tersebut disebutkan secara lengkap sanad dan matanya. $^{20}$

Kegiatan takhrīj al-ḥadís dilakukan dengan dua langkah; langkah pertama, menelusuri keberadaan hadis di berbagai kitab hadis dengan menggunakan software al-Maktabah al-Syāmilah. Kata kunci yang digunakan dalam penelusuran adalah . Dكرمة للنساء. Dari penelusuran yang dilakukan, ditemukan kata tersebut tersebar di 2010), 28

${ }^{13}$ Daniel Juned, Ilmu Hadis; Paradigma Baru dan Rekonstruksi Ilmu Hadis (tk: Erlangga,

${ }^{14}$ Syuhudi Ismail, Metodologi Penelitian Hadis Nabi (Jakarta: Bulan Bintang, 1992), h.24

${ }^{15}$ Abd al-Muhdi bin Abd al-Qadir bin Abd al-Hadi, 'Ilm al-Jarh wa al-Ta'dil; Qawā'iduh wa Aimmatuh, (al-Qāhirah: ttp, 1998), h. 9

16 Muhammad Mustafa al-'Azami, Manhaj al-Naqd 'Inda al-Muhaddisīin: Manhajuh wa Tarikhu, (Riyāḍ: Dār al-Kausar: 1990), h. 5

17 Ikramullah Imdad al-Haq, Al-Imām 'Ali al-Madini wa Manhajuh fi Naqd al-RijāI (Makkah: Dār al-Basyāir al-Islamiyah, tth), h. 17

${ }^{18}$ Syuhudi Ismail, Metodologi Penelitian Hadis Nabi (Jakarta: Bulan Bintang, 1992), h. 25

${ }^{19}$ Mahmud al-Tahhan, Ușūl al-Takhrīj wa Dirāsah al-Asānid (Riyād: Maktabah al-Ma'arif, 1991), h. 8-10. Abu Muhammad Abd al-Hadi bin Abd al-Qadir bin Abd al-Hadi, Turuq Takhrij Hadis Rasulillah, (al-Qāhirah: Dār al-'It ișām, tth), h.9-10

${ }^{20}$ Abdul Rahman Sakka, "Salat Sunah Enam Rakaat Setelah Magrib: Studi Kritik Hadis," AlAzhar Islamic Law Review, 2 No. 1 (Januari 2020): 4, doi.org/10.37146/ailrev.v2i1.32. 1-13 
beberapa kitab hadis; yakni Musnad Ahmad bin Hanbal, Mușannaf Ibn Abī Syaibah, al-Mu'jam al-Kabīr dan Sunan al-Baihaqi. Langkah kedua memastikan keberadaan hadis tersebut dengan mengunjungi langsung kitab yang dimaksudkan. Dari kunjungan langsung ditemukan satu sanad Ahmad bin Hanbal, satu sanad Ibn Abi Syaibah, lima sanad Al-țabrāni, dan tiga sanad al-Baihaqi. Lengkapnya dapat dilihat pada tabel berikut;

Tabel I :

Sebaran Hadis Pada Kitab-kitab Hadis

\begin{tabular}{|c|c|}
\hline Nama Kitab & Redaksi Hadis \\
\hline $\begin{array}{l}\text { Musnad } \\
\text { Ahmad bin Hanbal }\end{array}$ & أبيه، أن النبي صلى سريج، حدثنا عباد يعني ابن العوام، عن الحجاج، عن أبي المليح بن أسامة، عن \\
\hline $\begin{array}{l}\text { Muṣannaf } \\
\text { Ibn Abi Syaibah }\end{array}$ & 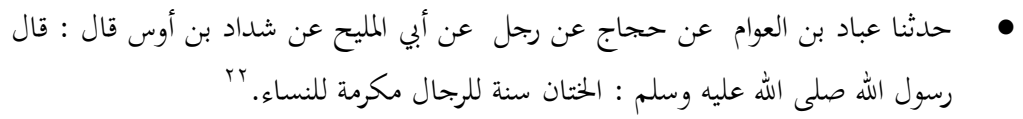 \\
\hline $\begin{array}{l}\text { Al-Mu'jam } \\
\text { al-Kabīr }\end{array}$ & 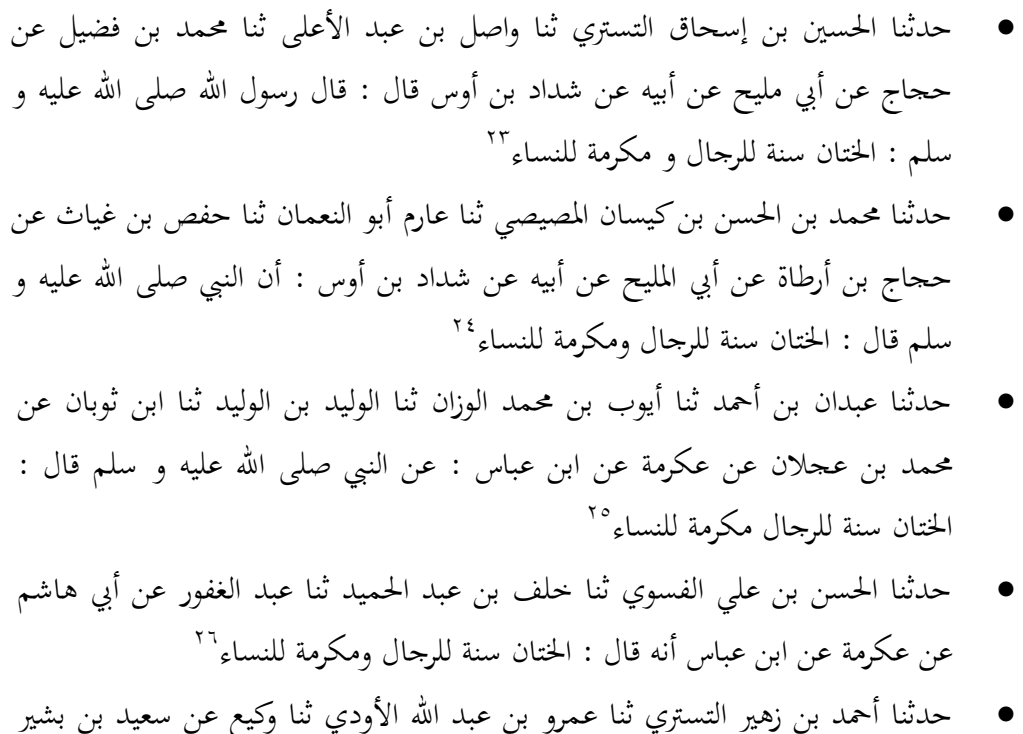 \\
\hline
\end{tabular}

${ }^{21}$ Abu Abdillah Ahmad bin Muhammad bin Hanbal bin Hilal bin Asad al-Syaibani (164-241 H), Musnad Ahmad bin Hanbal, Jilid 34, Cet. I (Beirut: Muassasah al-Risālah, 1994), h.319

${ }^{22}$ Abu Bakar Abdullah bin Muhammad bin Abi Syaibah al-Kufi (w.235 H), al-Kitāb alMuṣannaf fi al-Ahā dìi wa al-Aśār, Jilid 5, Cet. I (Beirut: Dar al-Tāj, 1989), h. 317

al-Qasim Sulaiman bin Ahmad bin Ayyub al-Tabrani (260-360 H), al-Mu'jam al-Kabïr, Jilid 7 (al-Qāhirah: Maktabah Ibn Taimiyah, tth), h. 329

23 Abu al-Qasim Sulaiman bin Ahmad bin Ayyub al-Tabrani (260-360 H), al-Mu'jam alKabïr, Jilid 7 (al-Qāhirah: Maktabah Ibn Taimiyah, tth), h. 329

${ }^{24}$ Abu al-Qasim Sulaiman bin Ahmad bin Ayyub al-Tabrani (260-360 H), al-Mu'jam alKabīr, Jilid 7 (al-Qāhirah: Maktabah Ibn Taimiyah, tth), h. 329

${ }^{25}$ Abu al-Qasim Sulaiman bin Ahmad bin Ayyub al-Tabrani (260-360 H), al-Mu'jam alKabïr, Jilid 11 (al-Qāhirah: Maktabah Ibn Taimiyah, tth), h. 233

${ }^{26}$ Abu al-Qasim Sulaiman bin Ahmad bin Ayyub al-Tabrani (260-360 H), al-Mu'jam alKabïr, Jilid 11 (al-Qāhirah: Maktabah Ibn Taimiyah, tth). h. 359 


\begin{tabular}{|c|c|}
\hline & عن قتادة عن جابر بن زيد عن ابن عباس : قال : الحتتان سنة للرجال مكرمة للنساءr \\
\hline $\begin{array}{l}\text { Sunan } \\
\text { al-Baihaqi } \\
\text { Kubrā }\end{array}$ & 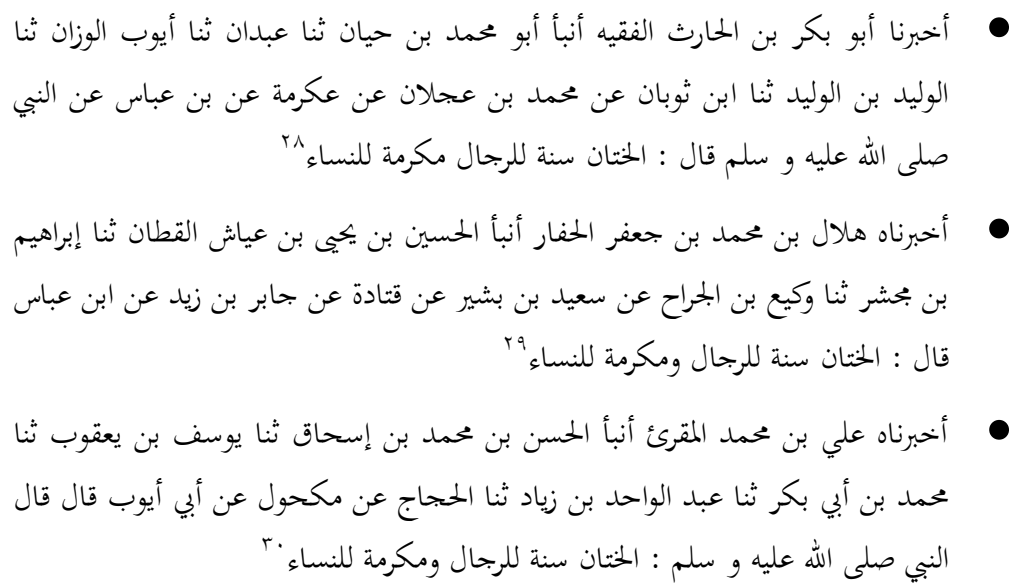 \\
\hline
\end{tabular}

\section{Al-I'tibār}

Al-'Itibār dalam kegiatan kritik sanad hadis merupakan tahap menghimpun seluruh sanad hadis agar dapat dilihat secara lengkap seluruh jalur sanad hadis yang diteliti, dan melihat ada tidaknya pendukung baik dalam bentuk mutābi' atau syāhid. ${ }^{31}$ Pada proses $\operatorname{takh} \bar{n} j$ (penelusuran) hadis sebelumnya, ditemukan hadis-hadis tentang khitan sebagai kehormatan bagi perempuan terkoleksi dalam empat kitab hadis Untuk memperjalas kegiatan al-i'tibār, keseluruhan jalur sanad akan digambarkan dalam bentuk skema sanad sebagai berikut;

${ }^{27}$ Abu al-Qasim Sulaiman bin Ahmad bin Ayyub al-Tabrani (260-360 H), al-Mu'jam alKabïr, Jilid 12 (al-Qāhirah: Maktabah Ibn Taimiyah, tth), h. 182

${ }^{28}$ Abu Bakar Ahmad bin al-Husain bin Ali al-Baihaqi (w.458 H), al-Sunan al-Kubra, Jilid 8 (Beirut: Dār al-Kutub al-Ilmiyah, 2003), h. 563

${ }^{29}$ Abu Bakar Ahmad bin al-Husain bin Ali al-Baihaqi (w.458 H), al-Sunan al-Kubra, Jilid 8 (Beirut: Dār al-Kutub al-Ilmiyah, 2003), h. 563

${ }^{30}$ Abu Bakar Ahmad bin al-Husain bin Ali al-Baihaqi (w.458 H), al-Sunan al-Kubra, Jilid 8 (Beirut: Dār al-Kutub al-Ilmiyah, 2003), h. 563

${ }^{31}$ Syuhudi Ismail, Metodologi Penelitian Hadis Nabi (Jakarta: Bulan Bintang, 1992), h. 52 


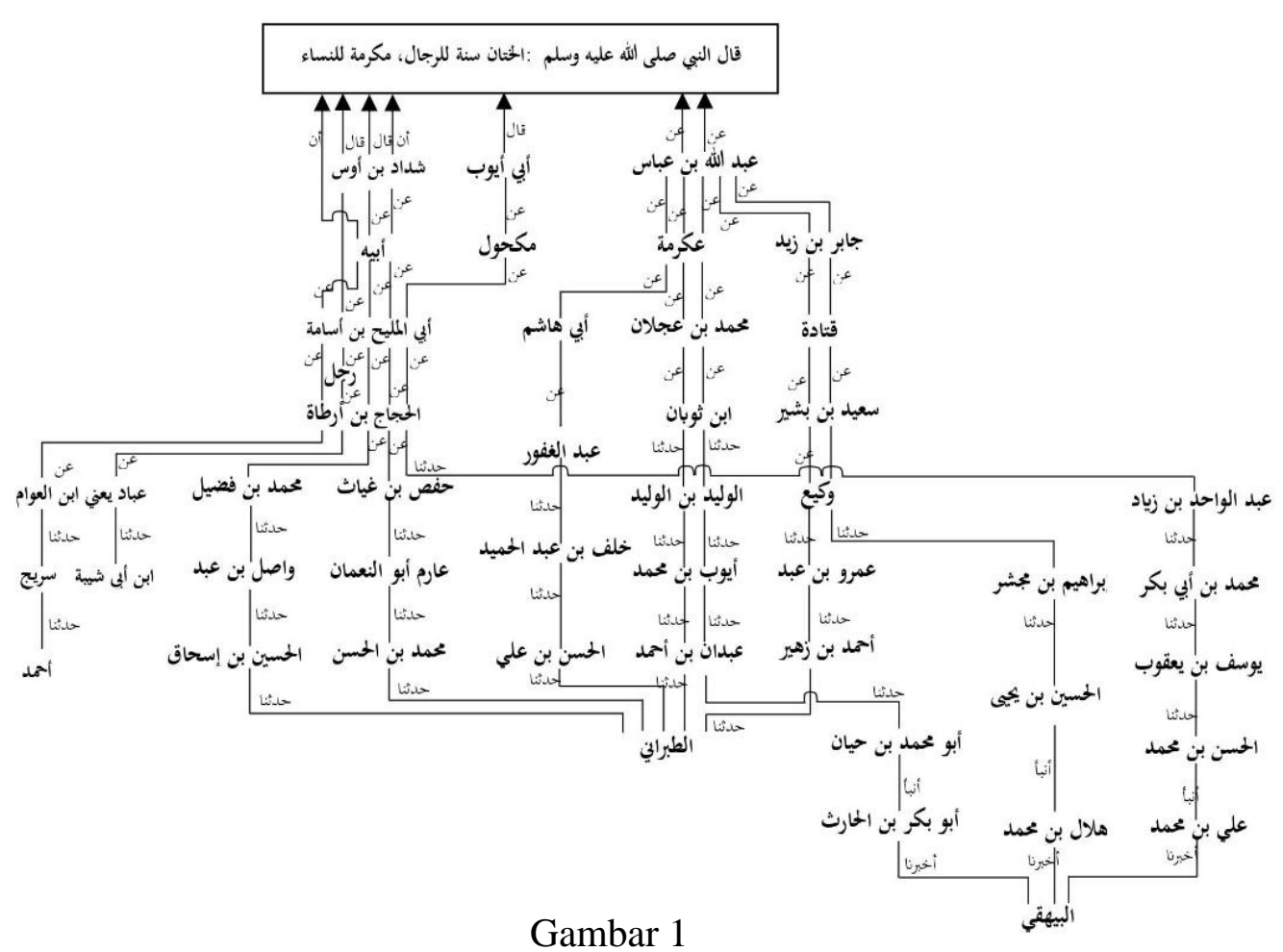

Skema Sanad Hadis Khitan Terhadap Perempuan sebagai Kehormatan

Dari gambar di atas, tampak jelas ada sepuluh sanad atau jalur periwayatan dari empat mukharrij (penghimpun hadis) yang mengklaim menerima hadis dengan jalurnya masing-masing. Dari sepuluh sanad tersebut, tujuh sanad marf'ü (sampai kepada Nabi SAW) dan tiga sanad mauqūf (tertahan hanya pada sahabat). Sanad marf $\bar{u}$ terbagi menjadi dua kelompok berdasarkan madar (poros) penyebaran hadis; pertama jalur al-Hajjaj bin Artah yang darinya terbentuk lima jalur sanad. Kedua jalur Abdan bin Ahmad yang darinya terbentuk dua jalur. Sedangkan sanad mauqū ada dua jalur yakni melalui Waki' yang darinya terbentuk dua jalur yakni sanad AlTabrani dan sanad al-Baihaqi dan satu jalur Ikrimah yang diriwayatkan al-Tabrani.

Jika ditetapkan riwayat Ahmad bin Hanbal sebagai hadis utama, maka dari gambar di atas terlihat dengan jelas sanadnya bersambung hingga kepada Nabi SAW melalui al-Hajjaj bin Artah dengan perawi tertingginya ayah dari Abu al-Malih bernama Usamah. Dari skema sanad tersebut dapat diketahui ada tiga perawi yang berstatus sebagai syāhid yaitu Syaddad bin Aus, Abu Ayyub dan Abdullah bin alAbbas. Dari Syaddad terbentuk tiga jalur yakni satu jalur sanad Ibn Abi Syaibah dan dua jalur sanad al-Tabrani, dari Abu Ayyub terbentuk satu jalur yakni sanad alBaihaqi, dan dari Abdullah bin al-Abbas terbentuk dua jalur yakni sanad al-Tabrani dan al-Baihaqi. Sedangkan yang perawi yang berstaus mutābi' pada sanad Ahmad bin Hanbal tidak ada. Dari skema sanad ini juga dapat diketahui kedudukan hadis dari sisi 'adad al-țruq (kuantitas) sebagai hadis masyhur karena diriwayatkan oleh minimal empat orang perawi di setiap tabaqah (tingkatan) sanad. 


\section{Menguji Kualitas Pribadi Perawi dan Metode Periwayatannya}

Dari hasil penelusuran sebelumnya terungkap bahwa hadis yang sedang diteliti berdasarkan sumbernya ada yang marf'ū dan ada yang mauqūf. Sanad hadis marf $\bar{u}$ berdasarkan madarnya terbagi dua; jalur al-Hajjaj bin Artah dan jalur Muhammad bin Ajlan. Sedangkan sanad hadis mauqū $f$ terdapat jalur Abdan bin Ahmad dan Ikrimah. Untuk memudahkan dalam menguji kualitas pribadi perawi yang terlibat dalam periwayatan serta metode periwayatan perawi, penulis akan menggunakan \pembagian jalur sanad berdasarkan madarnya.

\section{- Jalur al-Hajjaj bin Artah}

Pengujian kualitas perawi jalur al-Hajjaj bin Artah diawali dengan mengambil sanad al-Tabrani dari Al-Husain bin Ishaq sebagai sanad pertama yang diuji. Ada delapan perawi yang terlibat dalam mata rantai sanad. Sesuai urutan periwayatan, mereka adalah; Syaddad bin Aus - Abihi (ayahanda Abu Malih) bernama Usamah - Abu al-Malih - Al-Hajjaj bin Artah - Muhammad bin Fudail Wasil bin 'Abd al-'Ala - al-Husain bin Ishaq - al-Tabrani.

Syaddad bin Aus dan Usamah ayahanda Abu al-Malih keduanya sahabat Nabi saw. Nama lengkap Syaddad adalah Syaddad bin Aus bin Sabit bin al-Munzir Abu Ya'la. Wafat di Palestina pada tahun $57 \mathrm{H}$ diusia 75 tahun pada masa pemerintahan khalifah Muawiyah. Ia meriwayatkan hadis dari Nabi saw dan menjadi guru bagi penduduk Syam. ${ }^{32}$ Sedangkan Usamah (ayahanda Abu al-Malih) adalah sahabat Nabi saw yang menetap di Basrah. Nama aslinya Usamah bin Umair bin Amir bin Uqaisyir al-Huzali. Hadisnya diriwayatkan oleh anaknya Amir bin Usamah yang populer dikenal dengan nama Abu al-Malih. ${ }^{33}$

Menurut Kamaruddin Amin, sahabat Nabi menduduki posisi yang sangat menentukan dalam Islam. Mereka merupakan agen tunggal yang menyambungkan informasi kenabian dari Nabi saw kepada generasi berikutnya. Dari mereka al-Quran dan sunnah Nabi dapat diketahui. Atas dasar itulah mayoritas ulama menganggap semua sahabat adalah adil, dalam artian mereka terbebas dari penyebaran hadis palsu secara sengaja. $^{34}$

Abu al-Malih. Nama lengkapnya Abu al-Malih bin Usamah al-Huzali, ada yang mengatakan Amir atau Zaid bin Usamah bin Umair, atau Ibn Usamah bin Amir bin Umair bin Hunaif bin Najiah al-Basri. Ia meriwayatkan hadis dari bapaknya Usamah al-Huzali, Anas bin Malik, Jabir bin Abdullah dan beberapa sahabat lainnya. Yang meriwayatkan hadis darinya antara lain Qatadah, Abu Qilabah, dan Al-Hajjaj

${ }^{32}$ Abu al-Qasim Abdullah bin Muhammad bin Abd al-‘Aziz al-Bagawi (w. $217 \mathrm{H}$ ), Mu’jam al-Sahābat, Jilid 3 (Kuwait: Dār al-Bayān, tth), h. 283. Ahmad bin Abdullah bin Ahmad bin Ishaq bin Mahran al-Asbahani (w. 430), Ma'rifah al-Sahābat (Riyād: Dār al-Waṭan, 1998), h. 1459. Abu Umar Yusuf bin Abdullah bin Abd al-Barr al-Qurtubi al-Namari (w. 463 H), Al-Isti'āa fí Ma'rifah al-Aṣhāa (Ammān: Dār al-'Ilam, 2002), h. 329.

${ }^{33}$ Ahmad bin Abdullah bin Ahmad bin Ishaq bin Mahran al-Asbahāni (w. 430), Ma'rifah alSahāabat (Riyād: Dār al-Wațan, 1998), h. 227. Abu Umar Yusuf bin Abdullah bin Abd al-Barr alQurtubi al-Namari (w. 463 H), Al-Isti'āb fī Ma'rifah al-Aṣ̣āa (Amman: Dār al-'Ilam, 2002), h. 47

${ }^{34}$ Kamaruddin Amin, Menguji Kembali Keakuratan Metode Kritik Hadis (Jakarta: Hikmah, 2009), h. 48 
bin Arthah. Ia wafat tahun $112 \mathrm{H} .{ }^{35}$ Ulama kritikus hadis memberi penilaian positif. Ibn Hajar ${ }^{36}$, al-Zahabi, ${ }^{37}$ Ibn Hibban dan Abu Zur'ah ${ }^{38}$ memujinya sebagai perawi yang siqat (terpercaya).

Al-Hajjaj bin Artah. Nama lengkapnya Al-Hajjaj bin Artah bin Saur bin Hubairah bin Syarahil al-Kufi. Ia memiliki banyak guru, diantaranya Sabit bin Ubaid, al-Hasan bin Sa'ad, Ata bin Abi Rabah, Abu al-Malih. Ia juga memiliki banyak murid, antara lain Hafs bin Giyas dan Syu'bah bin al-Al-Hajjaj. wafat di Khurazan pada tahun 144,145 atau $147 \mathrm{H}^{39}$ Ulama memujinya sebagai seorang yang faqih, hafiz tetapi mereka menilainya negatif dalam hal periwatan. Menurut alDaraqutni, ia perawi yang ditulis hadisnya tetapi tidak bisa dijadikan hujah. ${ }^{40} \mathrm{Al}-$ Nasai mencelanya laisa bi al-qawi. ${ }^{41}$ Ibn Hajar menilainya saaū q, tapi banyak kesalahan dan tadiss. ${ }^{42}$ Al-Bukhari, ${ }^{43}$ al-Uqaili, ${ }^{44}$ Ibn al-Jauzi, ${ }^{45}$ dan al-Zahabi, ${ }^{46}$ semuanya menilai daif karena persoalan tadtis. Demikian pula al-Nasai, Yahya bin al-Qattan, Ibn al-Mubarak, Yahya bin Ma'in, dan Ahmad sependapat mencelanya sebagai seorang mudallis. ${ }^{47}$

Al-'Ijli mengungkapkan bahwa ia banyak meriwayatkan hadis dari seorang guru yang ia tidak pernah dengar, dan juga orang banyak mencelanya karena persoalan $\operatorname{tad} \hbar s^{48}$ Abu Zur'ah dan Abu Hatim menilainya șadùq tapi mudallis. Ia

\footnotetext{
35 Jamaluddin Abu al-Hajjaj Yusuf bin al-Mizzi (654-742 H), Tahīīb al-Kamāl fi Asma alRijāl, Jilid 34, Cet. II (Beirut: Muassasah al-Risālah, 1992), h. 317-318

36. Ahmad bin Ali bin Hajar al-Asqalani (773-852 H), Taqrīb al-Tahźib (tk: Dār al-Asimah, tth) h. 1210

${ }^{37}$ Syamsuddin Abu Abdillah Muhammad bin Ahmad bin Usman bin Qaimaz al-Zahabi (673748 H), Tażhīb Tahżīb al-Kamāl fi Asma al-Rijāl, Jilid 10, Cet. I (al-Qāhirah: al-Farūq al-Hadisìnah, 2004) h. 405

${ }^{38}$ Jamaluddin Abu al-Hajjaj Yusuf bin al-Mizzi (654-742 H), Tahżīb al-Kamāl fi Asma alRijāl, Jilid 34, Cet. II (Beirut: Muassasah al-Risālah, 1992), h. 317

39. Jamaluddin Abu al-Hajjaj Yusuf bin al-Mizzi (654-742 H), Tahżīb al-Kamāl fi Asma alRijāl, Jilid 5, Cet. II (Beirut: Muassasah al-Risālah, 1992), h. 422-423

40 Syamsuddin Abu Abdillah Muhammad bin Ahmad bin Usman bin Qaimaz al-Zahabi (673-748 H), Mizān al- 'Itidāl fi Naqd al-Rijāl, Jilid 2, Cet I (Beirut: Dār al-Kutub al-'Ilmiyah, 1995) h. 197 .

${ }^{41}$ Abu Abdirrahman Ahmad bin Syuaib al-Nasai (w. 303), Kitāb al-Du'afā wa al-Matrūkīn, (Beirut: Muassasah al-Kutub al-S|aqafah, 1985), h. 79

${ }^{42}$ Ahmad bin Ali bin Hajar al-Asqalani (773-852 H), Taqrīb al-Tahžib (tk: Dār al-Asimah, th) h. 222

43 Abu Abdillah Muhammad bin Ismail al-Bukhari (w.265 H), Kitāb al-Ḍu'afã al-Sagìr (Beirut: Dār al-Ma'rifah, 1986) h. 35

${ }^{44}$ Abu Ja'far Muhammad bin Amru bin Musa bin Hammad al-'Uqaili (w.322 H), Kitāb alDúafa, Jilid 1 (Riyād: Dār al-Sami’i, 2000) h. 297

45 Jamaluddin Abu al-Faraj Abdurrahman bin Ali bin Muhammad bin al-Jauzi, Kitāb alDư'afā wa al-Matrūkīn, (Beirut: Dār al-Kutub al-Ilmiyah, 1986) h. 191

${ }^{46}$ Syamsuddin Abu Abdillah Muhammad bin Ahmad bin Usman bin Qaimaz al-Zahabi (673748 H), Al-Mugni fi al-Du’afã, (Qatar: Idārah Ihya al-Turas, th) h. 234

47 Jalaluddin al-Suyuti (w. 911 H), Kitāb Asmā al-Mudallisīn, (Beirut: Dār al-Jail, 1992), h. 35

${ }^{48}$ Abu al-Hasan Ahmad bin Abdullah bin Salih al-'Ijli al-Kufi (182-261 H), Ma'rifah alSiqāt min Rijāl Ahl al-'Ilm wa al-Hadìs wa min al-Ḍu'afã wa Żikr Mazahibim wa Akhbarihim, Jilid 1 (al-Qāhirah: Matba'ah al-Madani, tth) h. 284
} 
melakukan tadis dari perawi yang lemah. Tetapi Abu Hatim tetap memujinya sebagai pribadi yang saleh yang tidak diragukan kejujuran dan hafalannya jika ia menegaskan bahwa ia mendengar langsung hadis yang diriwayatkan. Menurut Ahmad bin 'Adi, orang mencelanya karena telah melakukan tadts dari Zuhri maupun yang lainnya. Ia memang melakukan kesalahan di beberapa riwayat, bukan karena sengaja berdusta. Karena itu Muslim menerima hadisnya jika maqnūnan bigairih (ada riwayat lain yang siqat yang menguatkannya baik statusnya sebagai mutābi atau syāhid). ${ }^{49}$

Berdasarkan uraian di atas, dapat dipahami bahwa ulama kritikus hadis memuji Al-Hajjaj sebagai pribadi yang baik dari sisi kefaqihan dan hafalannya hingga ada yang menilainya șadū $q$, tetapi mereka mencelanya dalam hal periwayatan hadis. Hampir seluruh ulama kritikus hadis mencelanya sebagai seorang mudallis dengan keterangan yang jelas. Ibn Hajar al-Asqalani menggolongkannya sebagai perawi mudallis yang parah dengan level keempat dari lima level mudallis. Perawi mudallis level empat adalah perawi yang hadisnya tidak bisa sama sekali dijadikan hujah karena banyak melakukan tadīs dari perawi lemah dan perawi majhū $l$, kecuali jika ia menyebutkan secara jelas dan tegas dengan lambang periwayatan yang eksplisit bahwa ia mendengar langsung dari seorang guru. Abu Hatim dengan tegas mengatakan bahwa, kalaupun Al-Hajjaj menggunakan lambang periwayatan haddaśanā, hadisnya hanya dapat dinilai salih (baik) dan tetap tidak kuat. ${ }^{50}$ Dengan demikian riwayat Al-Hajjaj bin Artah dari Abu al-Malih dapat diterima jika keterangannya kuat bahwa ia menerima langsung hadisnya dengan bukti pernyataan eksplisit.

Muhammad bin Fudail. Yaitu Muhammad bin Fudail bin Gazwan bin Jarir al-Dabbi al-Kufi. Ia meriwayatkan hadis dari al-Hajjaj bin Dinar, al-Hajjaj bin Artah, al-Hasan bin al-Hakam dan lainnya. Yang meriwayatkan hadis darinya adalah; Ibrahim bin Said, Wasil bin Abd al-'Ala. Ia wafat pada tahun 195. ${ }^{51}$ Ulama kritikus hadis memberikan penilaian yang beragama; Usman bin Said al-Darimi dari Yahya bin Main berkata bahwa Muhammad bin Fudail siqat. Abu Zur'ah menilainya șadūq, al-Nasai menilai lā ba'sa bih, Ibn Main memujinya siqat, Ibn Hibban dan Abu Daud menilainya syiah fanatik. ${ }^{52}$ Menurut Ibn Hajar, ia seorang perawi șadūq, namun dituduh syiah. ${ }^{53}$

Berdasarkan penilaian ulama kritikus hadis di atas dapat dipahami bahwa Muhammad bin Fudail adalah seorang perawi syiah fanatik. Meskipun ia seorang syiah, ulama tidak mempermasalahkannya dan memujinya sebagai perawi yang

\footnotetext{
49. Jamaluddin Abu al-Hajjaj Yusuf bin al-Mizzi (654-742 H), Tahżīb al-Kamāl fi Asma alRijāl, Jilid 5, Cet. II (Beirut: Muassasah al-Risālah, 1992), h. 426-427.

50. Ahmad bin Ali bin Muhammad bin Muhammad bin Ali bin Hajar al-'Askalani al-Misri al-Syafii (w. 852 H), Tabaqāt al-Mudallisin, (Maktabah al-Manar: al-Zarqa, tth), h. 13 dan 48

${ }^{51}$ Jamaluddin Abu al-Hajjaj Yusuf bin al-Mizzi (654-742 H), Tahżīb al-Kamāl fi Asma alRijāl, Jilid 26, Cet. II (Beirut: Muassasah al-Risālah, 1992), h. 298

${ }^{52}$ Syamsuddin Abu Abdillah Muhammad bin Ahmad bin Usman bin Qaimaz al-Zahabi (673748 H), Mizān al-'Itidāl fi Naqd al-Rijāl, Jilid 6, Cet I (Beirut: Dār al-Kutub al-'Ilmiyah, 1995), h. 300 th) h. 889

${ }^{53}$ Ahmad bin Ali bin Hajar al-Asqalani (773-852 H), Taqrīb al-Tahżib (tk: Dār al-Asimah,
} 
șadūq bahkan siqat sehingga riwayatnya diterima. Ia merupakan salah seorang rijā 1 hadis Imam al-Bukhari ${ }^{54}$ dan Muslim. ${ }^{55}$

Wasil bin 'Abd al-'Ala. Nama lengkapnya Wasil bin 'Abd al-'Ala bin Hilal al-Asadi Abu al-Qasim al-Kufi dikenal sebagai perawi yang baik dan terpercaya. Ibn Hibban, ${ }^{56}$ Ibn Hajar, ${ }^{57}$ al-Zahabi, ${ }^{58}$ dan al-Nasai ${ }^{59}$ menilainya siqat, sedangkan Abu Hatim menilainya șadūq. ${ }^{60}$ Wafat tahun $244 \mathrm{H}$.

Al-Husain bin Ishaq. Informasi tentang dirinya tidak terekam baik dalam kitab biografi perawi. Al-Mizzi hanya menyebutnya di biografi Wasil bin Al-'Ala sebagai salah seorang muridnya yang meriwayatkan hadis darinya. ${ }^{61}$ Biografinya dituliskan secara singkat oleh al-Zahabi dalam kitab Siyar al-Nubala. Al-Zahabi mencatat bahwa ia bernama lengkap Al-Husain bin Ishaq bin Ibrahim al-Tustari alDaqiq, ia termasuk perawi yang banyak hafalannya dan hadisnya banyak diriwayatkan oleh Abu al-Qasim al-Tabrani. Wafat pada $290 \mathrm{H}^{62}$

Berdasarkan penilaian para kritikus hadis dapat disimpulkan bahwa para perawi yang terlibat dalam sanad hadis Al-Tabrani adalah perawi yang terpercaya, kecuali al-Hajjaj bin Artah yang dicela mudallis.

Setelah mengetahui keadaan perawi yang terlibat dalam periwayatan, selanjutnya akan dianalisis peluang pertemuan atau sezamannya antar perawi serta lambang periwayatan hadis yang digunakan oleh masing-masing perawi dalam meriwayatkan hadis yang bersangkutan.

Merujuk kepada data wafat dan tabaqah (tingkatan) seluruh perawi dapat dinilai bahwa antar perawi semuanya sezaman dan peluang terjadi pertemuan. Sedangkan lambang periwayatan yang digunakan ada dua; haddaśanā dan 'an. AlTabrani hingga Wasil menggunakan kata haddasiana, lambang periwayatan dengan pernyataan yang eksplisit. Selanjutnya Muhammad bin Fudail hingga Syaddad bin Aus menggunakan lambang yang ambigu ( 'an).

Al-Hajjaj bin Artah yang sebelumnya telah ditetapkan sebagai perawi mudallis ternyata meriwayatkan hadis dari Abu al-Malih dengan pernyataan ambigu

\footnotetext{
${ }^{54}$ Abu Nasr Ahmad bin Muhammad bin al-Husain al-Bukhari al-Kalabazi (323-397 H), Rijāl Sahịh al-Bukhāri, Jilid 2 (Beirut: Dār al-Marifah, 1987) h.674

${ }^{55}$ Abu Bakar Ahmad bin Ali bin Manjuwaih al-Asbahani (347-428 H), Rijāl Șahīh Muslim, Jilid 2 (Beirut: Dār al-Marifah, tth.) h. 201

${ }^{56}$ Muhammad bin Hibban bin Ahmad Abu Hatim al-Tamimi (w. 354 H), Kitab al-Siqāt, Jilid 9 (Hindi: Maktabah Dār al-Ma'ārif, 1973) h. 231

${ }^{57}$ Ahmad bin Ali bin Hajar al-Asqalani (773-852 H), Taqrīb al-Tahźib (tk: Dār al-Asimah, tth) h. 1033

${ }^{58}$ Syamsuddin Abu Abdillah Muhammad bin Ahmad bin Usman bin Qaimaz al-Zahabi (673748 H), Tażhīb Tahżīb al-Kamāl fi Asma al-Rijāl, Jilid 10, Cet. I (al-Qāhirah: al-Farūq al-Hadisìnah, 2004) h. 336

59 Jamaluddin Abu al-Hajjaj Yusuf bin al-Mizzi (654-742 H), Tahżīb al-Kamāl fi Asma alRijāl, Jilid 30, Cet. II (Beirut: Muassasah al-Risālah, 1992), h. 405

60 Abu Muhammad Abdurrahman bin Abi Hatim Muhammad bin Idris bin al-Munzir alTamimi al-Razi (w. 327 H), Kitāb al-Jarḥ wa al-Ta’dil, juz 9, (Beirut: Dār al-Kutub al-Ilmiah, 1953) h. 32

${ }^{61}$ Jamaluddin Abu al-Hajjaj Yusuf bin al-Mizzi (654-742 H), Tahìīb al-Kamāl fi Asma alRijāl, Jilid 30, Cet. II (Beirut: Muassasah al-Risālah, 1992), h. 403

${ }^{62}$ Syamsuddin Abu Abdillah Muhammad bin Ahmad bin Usman bin Qaimaz al-Zahabi (673748 H), Siyar al- 'Alām al-Nubalā, Jilid 14, Cet. III (Beirut: Muassasah al-Risalah, 1983) h.57
} 
('an). Dengan posisinya sebagai golongan perawi mudallis level empat, maka dapat dipastikan bahwa riwayatnya dari Abu al-Malih cacat dan sulit diterima. Dengan demikian sanad hadis Al-Tabrani jalur al-Hajjaj bin Artah dinyatakan daif sehingga tidak bisa dijadikan hujah. Posisi Al-Hajjaj bin Artha sebagai poros penyebaran hadis berdampak pada empat jalur sanad lainnya. yakni sanad Ahmad, Ibn Abi Syaibah, alBaihaqi dan satu sanad Al-Tabrani lainnya otomatis daif karena semuanya melalui Al-Hajjaj bin Artah.

\section{- Jalur Abdan bin Ahmad.}

Abdan bin Ahmad membangun riwayatnya secara tunggal dari Ayyub bin Muhammad dari al-Walid bin al-Walid dari Ibn Sauban dari Muhammad bin Ajlan dari Ikrimah dari Abdullah bin Abbas Nabi saw. Lalu darinya terbentuk dua jalur riwayat; jalur Al-Tabrani dan al-Baihaqi. Pada sanadnya ini terdapat perawi bernama al-Walid bin al-Walid yang dipermasalahkan.

Nama lengkapnya al-Walid bin al-Walid al-'Anasi al-Qalanisi al-Dimasyqi. Menurut Ibn Hibban, ia meriwayatkan nuskhah (catatan) dari Ibn Sauban yang sebagian besarnya maqhu $b$. Karena itu hadis-hadisnya dari Ibn Sauban tidak bisa dijadikan hujah. ${ }^{63}$ Al-Daraqutni menilainya munkar al-hadi $\dot{s}^{64}{ }^{64}$ Menurut Abu Nuaim al-Asbahani, ia meriwayatkan hadis palsu dari Muhammad bin Abdirrahman bin Sabit, sedangkan Abu Hatim menilainya șadūq. ${ }^{65}$ Al-Baihaqi sendiri telah menyatakan sanad hadis ini daif, riwayat yang mahfü $z$ adalah yang mauqū $f^{66}$

Tampaknya terkumpul pujian (ta'dîl) dan celaan (jarh) pada diri al-Walid. Abu Hatim memujinya șadūq, sedangkan Ibn Hibban, al-Daraqutni, Abu al-Nuaim dan al-Baihaqi mencelanya. Untuk kasus ini, kritikan yang mencelanya didahulukan dan dikuatkan dari yang memberinya pujian karena dua alasan; pertama, ulama yang mencelanya lebih banyak dari yang memujinya. Kedua, ulama yang memujinya tidak memberikan alasan keterpujiannya, sedangkan ulama yang mencelanya disertai penjelasan ketercelaannya. Ibn Hibban secara tegas menyatakan bahwa riwayat alWalid dari Ibn Sauban tidak bisa dijadikan hujah karena sebagian besarnya maqhūb.

Hadis maqhūb (terbolak balik) adalah terjadinya pertukaran, penggantian atau pemutarbalikan kata dari kata-kata yang terdapat pada sanad dan atau matan hadis. Apabila tertukarnya kata disebabkan karena kesalahan dan kekeliruan dalam jumlah yang banyak dan berlebihan maka tidak lagi d̦ābit dan otomatis hadisnya daif. Jika ada kesengajaan mengganti seorang perawi dengan perawi lain dengan maksud

${ }^{63}$ Muhammad bin Hibban bin Ahmad bin Abi Hatim al-Tamimi (w. $\left.354 \mathrm{H}\right)$, Kitāb alMajrūhịn inda al-Muhaddis̄in wa al-Ḍu'afā wa al-Matrūkìn, Jilid 3 (Beirut: Dār al-Marifah, 1992), h.81.

${ }^{64}$ Abu al-Hasan Ali bin Umar al-Daraqutni al-Bagdadi (w.385 H), al-Ḍu'afã wa al-Matrūkỉn (Riyad: Maktabah al-Ma'ārif, 1984), h.386. Syamsuddin Abu Abdillah Muhammad bin Ahmad bin Usman bin Qaimaz al-Zahabi (673-748 H), Mizān al-'Itidāl fi Naqd al-Rijāl, Jilid 7 (Beirut: Dār alKutub al-Ilmiah, 1995), h. 144

${ }^{65}$ Ahmad bin Ali bin Hajar al-Asqalani (773-852 H), Lisān al-Mizān, Jilid 8, Cet. I (Beirut: Dār al-Basyair, 1992), h.394.

${ }^{66}$ Lihat kembali Abu Bakar Ahmad bin al-Husain bin Ali al-Baihaqi (w.458 H), al-Sunan alKubrā, Jilid 8 (Beirut: Dār al-Kutub al-Ilmiyah, 2003), h. 563 
menghilangkan jejak atau menyamarkan perawi maka itu merupakan amalan para pemalsu hadis. ${ }^{67}$

Jika dipertemukan pendapat Abu Nuaim al-Asbahani dengan pendapat Ibn Hibban maka dapat dikatakan bahwa Al-Walid adalah perawi hadis maqhüb dengan tujuan sengaja melakukan tagn̄ b (menghilangkan jejak) perawi. Apa yang dilakukannya merupakan perbuatan pemalsu hadis yang sangat tercela. Dengan demikian sanad hadis al-Daraqutni dan al-Baihaqi jalur Abdan bin Ahmad ini dinyatakan daif karena keberadaan al-Walid bin al-Walid yang nyata cacatnya. Kecacatan al-Walid tergolong berat karena dicela sebagai perawi maqhüb karena motif menghilangkan jejak.

Berdasarkan hasil analisa kritis terhadap jalur Al-Hajjaj bin Artah dan Abdan bin Ahmad, dapat disimpulkan bahwa semua jalur sanad yang melewati keduanya dinyatakan bermasalah. Dengan demikian hadis riwayat Ahmad bin Hanbal, Ibn Abi Syaibah, al-Dararaqutni dan al-Baihaqi adalah daif dengan tingkat kedaifan yang berat. Ini berarti tidak ada hadis marf' $\bar{u}$ tentang khitan perempuan sebagai kehormatan yang berstatus sahih dan bisa menjadi hujah. Selanjutnya akan dikritisi tiga jalur sanad hadis yang mauqū fmelalui Waki' dan Ikrimah.

\section{- Jalur Waki'}

Waki' menyambungkan riwayatnya secara tunggal melalui Sa'id bin BasyirQatadah-Jabir bin Zaid hingga Abdullah bin Abbas. Lalu dari Waki' tersiar hadis dan membentuk dua jalur periwayatan yang dicatatkan Al-Tabrani dan al-Baihaqi. Pada jalur ini, Sai'd bin Basyir yang merupakan gurunya Waki' dipermasalahkan ulama. Nama lengkapnya Sa'id bin Basyir al-Azdi Abi Abdirrahman. Ia berasal dari Basrah kemudian berpindah ke Syam dan menetap di kota Damaskus hingga wafat pada tahun $170 \mathrm{H}$ pada awal pemerintahan Harun al-Rasyid. ${ }^{68}$ Mayoritas ulama mencelanya. Ibn Hajar, ${ }^{69}$ Al-Nasai ${ }^{70}$ dan Al-Uqaily ${ }^{71}$ mencela Said bin Basyir sebagai perawi daif. Ibn al-Numair menjelaskan kedaifannya adalah sebagai perawi hadis munkar terutama dari Qatadah. ${ }^{72}$ Riwayatnya dari Qatadah tidak punya mutā $b a{ }^{\prime} a h^{73}$

\footnotetext{
${ }^{67}$ Manna al-Qattan, Mabāḥis̉ fi 'Ulūm al-Hadis (al-Qāhirah: Maktabah Wahbah, 1992), h. $143-144$

${ }^{68}$ Muhammad bin Saad bin Mun'i al-Zuhri (w. 230 H), Kitāb Tabaqāt al-Kubrā, Jilid 9, (alQāhirah: Maktabah al-Khanji, 2001)472 tth), h.374

${ }^{69}$ Ahmad bin Ali bin Hajar al-Asqalani (773-852 H), Taqrīb al-Tahźib (tk: Dār al-'Āṣimah,

70 Abu Abdirrahman Ahmad bin Syuaib al-Nasai (w. 303 H), Kitāb al-Ḍu'afà wa alMatrūkin, (Beirut: Muassasah al-Kutub al-Saqafiyah, 1985), h. 112

${ }^{71}$ Abu Ja'far Muhammad bin Amru bin Musa bin Hammad al-'Uqaili (w.322 H), Kitāb alDu'afa, Jilid 2 (Riyād: Dār al-Sami'i, 2000), h. 460

72 Jamaluddin Abu al-Faraj Abdurrahman bin Ali bin Muhammad bin al-Jauzi, Kitāb alDúafã wa al-Matrūkīn, Jilid 1 (Beirut: Dār al-Kutub al-Ilmiyah, 1986) h. 314. Jamaluddin Abu alHajjaj Yusuf bin al-Mizzi (654-742 H), Tahżīb al-Kamāl fi Asma al-Rijāl, Jilid 10, Cet. II (Beirut: Muassasah al-Risālah, 1992), h.348

${ }^{73}$ Syamsuddin Abu Abdillah Muhammad bin Ahmad bin Usman bin Qaimaz al-Zahabi (673748 H), Dīwān al-Ḍ'afã wa al-Matrūkin̄, Cet. II (Mekkah: Maktabah al-Nahdah al-Hadisiyah, th), h. 156. Jamaluddin Abu al-Faraj Abdurrahman bin Ali bin Muhammad bin al-Jauzi, Kitāb al-Dúafä wa al-Matrūkinn, Jilid 1 (Beirut: Dār al-Kutub al-Ilmiyah, 1986), h. 315
} 
Ibn Hibban menjelaskan kedaifannya adalah karena hafalannya buruk dan fahisy alkhata (kesalahan yang parah). Selain yang mencela, beberap ulama memujinya. Syu'bah dan Duhaim menilainya siqat, al-Bazzar menilainya șālih̆, lā basa bih dan baik hadisnya, Abu Zur'ah menilai al-șidq (terpuji). Berdasarkan pujian tersebut sehingga riwayatnya bisa menjadi mutaba'ah atau syawahid (penguat). ${ }^{74}$

Jika dianalisis perbedaan pendapat ulama dalam menilai Said bin Basyir di atas dengan menggunakan kaidah al-jarh wa al-ta'dil, maka penilaian ulama yang mencelanya lebih kuat dari yang memujinya karena tuduhan ketercelaan disertai dengan penjelasan tentang sebab-sebabnya. Ulama yang menilai Said bin Basyir daif karena hafalannya yang sangat jelek dan banyak melakukan kesalahan sehingga ia dianggap sebagai perawi munkar, terutama ketika meriwayatkan hadis dari Qatadah (sebagaimana dalam hadis ini). Ulama yang memujinya pun hanya menempatkan riwayatnya sebagai penguat saja bukan hujah utama. Dengan demikian sanad hadis al-Baihaqi dan Al-Tabrani jalur Waki' yang mauqū $f$ pada Ibn Abbas dinilai lemah sekali karena salah seorang perawinya cacat sebagai perawi munkar.

\section{- Jalur Ikrimah}

Satu jalur sanad yang dibangun al-Tabrani melalui Ikrimah, mauqū $f$ pada Ibn Abbas. Pada sanad ini ditemukan perawi bernama Abdul Gafur yang bermasalah. Nama lengkapnya Abu Al-Sabah Abdul Gafur bin Abdul 'Aziz bin Sa'id bin Sa'ad bin 'Ubadah al-Ansari al-Wasiti. Ia memiliki hubungan periwayatan dengan Abu Hasyim al-Rummani sebagai murid dari Abu Hasyim. ${ }^{75}$ Namun menurut Akram alAsari, ia adalah perawi munkar (munkar al-hadìs) dan ulama meninggalkan hadisnya (tarakuh). ${ }^{76}$ Ibn Hajar al-Asqalani mengutip beberapa komentar dan penilaian negatife ulama terhadap Abdul Gafur. Menurut Yahya bin Ma'in; laisa ḥadísu bisyai (tidak ada sesuatu pada hadisnya), Al-Bukhari menilainya hadisnya matrūk, Ibn Hibban menuduhnya memalsukan hadis, sedangkan Ibn Adi menilainya munkar alhadît. $^{77}$

Penilaian ulama terhadap Abdul Gafur antara munkar, matruk dan maudu'. Ketiga kategori kedaifan tersebut dalam ilmu hadis merupakan level kedaifan yang sangat tinggi yang sulit ditoleransi. Keberadaan Abdul Gafur bin Abdul 'Aziz sebagai perawi pada sanad al-Tabrani menyebabkan hadis ini menjadi hadis yang sangat lemah.

Berdasarkan hasil analisa kritik di atas, terungkap dengan jelas bahwa seluruh sanad hadis adalah daif karena kecacatan perawi. Dari empat poros periwayatan, lima jalur periwayatan yang melalui al-Al-Hajjaj bin Artah semuanya daif disebabkan oleh al-Al-Hajjaj bin Artah sendiri merupakan perawi yang bermasalah, yaitu

${ }^{74}$ Bassyar 'Awwad Ma'ruf wa Syu'aib al-Arnut, Tahrīir Taqrīb al-Tahżīb, Jilid 2, Cet. I (Beirut: Muassasah a-Risālah, 1997), h. 23

75 Jamaluddin Abu al-Hajjaj Yusuf bin al-Mizzi (654-742 H), Tahżib al-Kamāl fi Asma alRijāl, Jilid 34, Cet. II (Beirut: Muassasah al-Risālah, 1992), h. 363

${ }^{76}$ Ikram bin Muhammad Ziyadah al-Faluji al-Asari, Al-Mu'jam al-Sagīir li Ruwāt al-Imām Ibn Jarï al-Tabari (tk: Dār al-Asariyah, tth), h. 299

77 Ahmad bin Ali bin Hajar al-Asqalani (773-852 H), Lisān al-Mizān, Jilid 5, Cet. I (Beirut: Dār al-Basyāir, 1992). h. 230 
seorang mudallis perawi lemah. Dua jalur periwayatan yang melalui Abdan bin Ahmad juga daif karena seorang perawinya bernama al-Walid bin al-Walid adalah perawi maqhūb. Jalur periwayatan yang melalui Waki' semuanya bermasalah karena perawinya yang bernama Sa'id bin Basyir adalah perawi munkar, serta satu jalur yang melalui Ikrimah juga daif karena seorang perawinya bernama Abdul Gafur bin Abdul 'Aziz adalah perawi munkar dan matn̄ $k$.

\section{Beramal dengan Hadis Daif}

Ulama terbagi menjadi tiga kelompok terkait pengamalan hadis-hadis daif. Kelompok pertama berpendapat bahwa seluruh hadis daif tidak bisa diamalkan secara mutlak, baik dalam urusan akidah, hukum, motivasi, maupun fadilah amal. Kelompok kedua berpendapat bahwa hadis daif bisa diamalkan secara mutlak dalam semua urusan agama jika tidak ada hadis lain (sahih dan hasan) yang bisa menjadi dasar. Kelompok ketiga berpendapat bahwa tidak dibenarkan beramal dengan hadis daif dalam urusan akidah dan hukum halal haram, yang dibolehkan hanyalah dalam urusan fadilah amal dan motivasi dengan syarat; 1). Bukan hadis daif yang sangat lemah (gair syadid), 2). Hadis tersebut termasuk dalam kaidah utama syariat Islam yang diamalkan 3). Ketika mengamalkan hadis daif tidak diyakini kebenarannya, tetapi karena alasan kehati-hatian saja. ${ }^{78}$

Muhammad Yusram merangkum enam syarat yang ditetapkan ulama dalam meriwayatkan dan mengamalkan hadis daif; 1). Hadisnya bukan lemah sekali; 2). Ditunjuki oleh suatu dasar umum dan dipegangi yang berasal dari hadis sahih; 3). Tidak diyakini sebagai sabda Nabi saw; 4). Tidak termasuk dalam masalah akidah, hukum halal haram dan lainnya yang bersifat prinsip dalam agama; 5). Tidak mempopulerkan hadis yang diamalkannya kepada masyarakat awam yang bisa salah paham; 6). Dalam meriwayatkannya tidak menggunakan șigat jazm (bentuk pasti) seperti qā la Rasulullah saw. ${ }^{79}$

Berdasarkan kritik sanad sebelumnya, tergambar dengan jelas hadis khitan perempuan sebagai kehormatan merupakan hadis daif yang sangat lemah karena perawinya dicela perawi hadis mungkar, matn̄ $k$ dan mudallis sehingga tidak bisa dijadikan dalil termasuk dalam masalah fadāil. Karena itu, pencantuman MUI dalam fatwanya bahwa status hukum khitan perempuan adalah maknūmah sebagaimana disebutkan dalam dictum 1;2 dengan menggunakan hadis ini sebagai dalilnya adalah lemah dan perlu ditinjau ulang. Kalaupun hadis ini tetap diakomodir, maka hanya bisa menjadi pendukung (syāhid) hadis-hadis khitan lainnya yang sahih atau hasan untuk tujuan menguatkan kedudukan khitan bagi perempuan dalam makna umum, bukan karena alasan kehormatan.

${ }^{78}$ Manna al-Qattan, Mabāḥis̉ fi 'Ulūm al-Hadìs, (Al-Qāhirah: Maktabah Wahbah, 1992), h. 114.

79 Muhammad Yusram, "Hukum Meriwayatkan Dan Mengamalkan Hadis Daif Untuk Fadhail Al-A'mal," Nukhbatul 'Ulum 3, no. 1 (2017): 5, https://doi.org/10.36701/nukhbah.v3i1.17. 111 


\section{KESIMPULAN}

Ada sepuluh hadis tentang khitan perempuan sebagai kehormatan yang dihimpun oleh empat perawi mukharrij; yakni Ibn Abi Syaibah dengan satu sanad, Ahmad bin Hanbal satu sanad, Al-Tabrani lima sanad, dan al-Baihaqi tiga sanad. Dari sepuluh hadis tersebut, tujuh hadis marf'u (sumbernya dari Nabi SAW) dan tiga hadis mauqū $f$ (sumbernya dari sahabat).

Dari sisi 'adad al-țuruq (jumlah jalur) atau kuantitas, hadis ini dapat digolongkan sebagai hadis masyhur, karena pada tiap tabaqah (tingkatan) sanad terdapat minimal empat orang perawi. Adapun aspek quwah wa da'fuh (kualitas), hadis ini daif dengan tingkat kedaifan yang tinggi. Penyebab kedaifannya adalah kecacatan perawi yang terlibat dalam periwayatan. Perawi yang divonis cacat adalah al-Hajjaj bin Artah sebagai perawi mudallis pada jalur periwayatan Ahmad bin Hanbal, Ibn Abi Syaibah, dua jalur Al-Tabrani dan Al-Baihaqi. Al-Walid bin alWalid adalah perawi maqhūb tujuan $\operatorname{tag} \bar{\imath} \bar{b}$ pada jalur lain yang diriwayatkan alTabrani dan al-Baihaqi. Sa'id bin Basyir adalah perawi munkar pada hadis mauqūf riwayat al-Tabrani dan al-Baihaqi. Abdul Gafur bin Abdul 'Aziz adalah perawi munkar dan matrū $k$ pada hadis mauqū $f$ pada jalur lain al-Tabrani.

Hadis ini tidak bisa dijadikan dalil atau hujah utama khitan bagi perempuan, dan tidak tepat juga dijadikan sebagai hujah kesyariatan khitan bagi perempuan karena alasan maknummah (kehormatan). Hadis ini hanya dapat dijadikan sebagai dalil penguat terhadap hadis lain yang sahih atau hasan yang memang menyebutkan secara jelas dan tegas tentang praktek khitan bagi perempuan merupakan bagian dari syariat Islam. Karena itu pencantuman dalam fatwa MUI sebagai dalil utama pembenaran khitan bagi perempuan perlu ditinjau ulang dan dipertimbangkan mengingat hadis ini sangat lemah.

\section{DAFTAR PUSTAKA}

Abd. al-Hadi, Abu Muhammad Abd al-Hadi bin Abd al-Qadir. Turuq Takhrīj Hadīs Rasulillah. Al-Qāhirah ā: Dār al-'Itișām, tth. 'Ilm al-Jarh wa al-Ta'dīl; Qawā'iduh wa Aimmatuh. Al-Qāhirah: tp, 1998.

Al-Arnut, Bassyar 'Awwad Ma'ruf wa Syu'aib. Tahrīr Taqrīb al-Tahzīb, Jilid 2, Cet. I. Beirut: Muassasah a-Risālah, 1997.

Al-Asari, Ikram bin Muhammad Ziyadah al-Faluji. Al-Mu'jam al-Ṣaḡ̄r li Ruwāt alImām Ibn Jarìr al-Ṭabari. tk: Dār al-As'ariyah, tth.

Al-Asbahani, Ahmad bin Abdullah bin Ahmad bin Ishaq bin Mahran (w. 430). Ma'rifah al-Ṣahābat. Riyād: Dār al-Wațan, 1998.

Al-Asbahani, Abu Bakar Ahmad bin Ali bin Manjuwaih (347-428 H). Rijāl Ṣahīh Muslim, Jilid 2. Beirut: Dār al-Marifah, tth.

Al-Syaibani, Abu Abdillah Ahmad bin Muhammad bin Hanbal bin Hilal bin Asad (164-241 H). Musnad Ahmad bin al-Hanbal, no. hadis 20719, Jilid 34 Cet. I. Beirut: Mu'assasah al-Risālah, 1994.

Al-'Azami, Muhammad Mustafa. Manhaj al-Naqd 'Inda al-Muhaddisinn: Manhajuh wa Tarīkhu. Riyāḍ: Dār al-Kauṣar: 1990. 
Al-Asqalani, Ahmad bin Ali bin Muhammad bin Muhammad bin Ali bin Hajar alMisri al-Syafi'i (773-852 H). Taqrīb al-Tahzib. tk: Dār al-Asimah, th.

. Tabaqāt al-Mudallisìn. Maktabah al-Manar: al-Zarqa, tth. . Lisān al-Mizān, Jilid 8, Cet. I. Beirut: Dār al-Basyair, 1992.

Al-Haq, Ikramullah Imdad. Al-Imām 'Ali al-Madīni wa Manhajuh fi Naqd al-Rijāl. Makkah: Dār al-Basyāir al-Islamiyah, tth.

Al-Baihaqi, Abu Bakar Ahmad bin al-Husain bin Ali (w.458 H). Al-Sunan al-Kubrā, Jilid 8. Beirut: Dār al-Kutub al-Ilmiyah, 2003.

Al-Bagawi, Abu al-Qasim Abdullah bin Muhammad bin Abd al-'Aziz (w. 217 H). Mu'jam al-Ṣahāabat, Jilid 3 (Kuwait: Dār al-Bayān, tth.

Al-Bukhari, Abu Abdillah Muhammad bin Ismail. (w.194-256 H). Kitāb al-Du'afā al-Șagīr. Beirut: Dār al-Ma'rifah, 1986.

Al-Daraqutni, Abu al-Hasan Ali bin Umar al-Dāraqutni al-Bagdadi (w.385 H). AlDu'afā wa al-Matrūkīn. Riyad: Maktabah al-Ma'ārif, 1984.

Al-'Ijli, Abu al-Hasan Ahmad bin Abdullah bin Salih al-Kufi (182-261 H). Ma'rifah al-Tsiqāt min Rijāl Ahl al-'Ilm wa al-Hadīs $\backslash$ wa min al-Du'afā wa Zikr Mazāhibim wa Akhbārihim, Jilid 1. Al-Qāhirah: Matba'ah al-Madani, tth.

Al-Jauzi, Jamaluddin Abu al-Faraj Abdurrahman bin Ali bin Muhammad. Kitāa aldu'afā wa al-Matrūkīn, Jilid 1. Beirut: Dār al-Kutub al-Ilmiyah, 1986.

Al-Kalabazi, Abu Nasr Ahmad bin Muhammad bin al-Husain al-Bukhari (323-397 H). Rijāl Sahih al-Bukhāri, Jilid 2. Beirut: Dār al-Marifah, 1987.

Al-Mizzi, Jamaluddin Abu al-Hajjaj Yusuf (654-742 H). Tahzīb al-Kamāl fi Asma al-Rijāl, Jilid, 10, 34, Cet. II. Beirut: Muassasah al-Risālah, 1992.

Al-Namari, Abu Umar Yusuf bin Abdullah bin Abd al-Barr al-Qurtubi (w. $463 \mathrm{H}$ ), Al-Isti' āb fì Ma'rifah al-Aṣhāo (Ammān: Dār al-'Ilam, 2002.

Al-Nasai, Abu Abdirrahman Ahmad bin Syuaib (w. 303). Kitāb al-Du'afā wa alMatrūkīn. Beirut: Muassasah al-Kutub al-S|aqafah, 1985.

Al-Razi, Abu Muhammad Abdurrahman bin Abi Hatim Muhammad bin Idris bin alMunzir al-Tamimi al-Razi (w. 327 H). Kitāb al-Jarh wa al-Ta'dīl, Jilid 9. Beirut: Dār al-Kutub al-Ilmiah, 1953.

Al-Tahhan, Mahmud. Ușūl al-Takhrīj wa Dirāsah al-Asānid. Riyād: Maktabah alMa'arif, 1991.

. Taisīr Muștalaḥ al-Hadīs. Al-Iskandāriyah: Markaz al-Hady li al-Dirāsat, $1415 \mathrm{H}$.

Al-Tabrani, Abu al-Qasim Sulaiman bin Ahmad bin Ayyub (260-360 H). Al-Mu'jam al-Kabìr, Jilid 7, 11, 12. Al-Qāhirah: Maktabah Ibn Taimiyah, th.

Al-Tamimi, Muhammad bin Hibban bin Ahmad Abu Hatim (w. 354 H). Kitāb alS\{ iqāt, Jilid 9. Hindi: Maktabah Dār al-Ma'ārif, 1973.

.Kitāb al-Majrūḥ̄n inda al-Muhaddisไ̄̄n wa al-Ḍu'afā wa al-Matrūkīn, Jilid 3. Beirut: Dār al-Marifah, 1992.

Al-'Uqaily, Abu Ja'far Muhammad bin Amru bin Musa bin Hammad (w.322 H). Kitāb al-Du'afa, Jilid 1, 2. Riyād: Dār al-Sami'i, 2000.

Al-Suyuti, Jalaluddin (w. 911 H). Kitāb Asmā al-Mudallisīn. Beirut: Dār al-Jail, 1992. 
Al-Qattan, Manna'. Mabāhis fi 'Ulūm al-Hadīs. Al-Qāhirah: Maktabah Wahbah, 1992.

Al-Zuhri, Muhammad bin Saad bin Mun'i al-Zuhri (w. 230 H). Kitāb Tabaqāt alKubrā, Jilid 9. Al-Qāhirah: Maktabah al-Khanji, 2001.

Al-Zahabi, Syamsuddin Abu Abdillah Muhammad bin Ahmad bin Usman bin Qaimaz (673-748 H). Tazhīb Tahzīb al-Kamāl fi Asma al-Rijāl, Jilid 10, Cet. I. Al-Qāhirah: al-Farūq al-Hadīsiyah, 2004 . Mizān al-'Itidāl fi Naqd al-Rijāl, Jilid 2, 7, Cet I. Beirut: Dār al-Kutub al'Ilmiyah, 1995. Al-Mugni fi al-Du'afā. Qatar: Idārah Ihya al-Turas, th. . Siyar al-'Alām al-Nubalā, Jilid 14, Cet. III. Beirut: Muassasah al-Risalah, 1983.

Dīwān al-Du'afā wa al-Matrūkin, Cet. II. Mekkah: Maktabah al-Nahdah alHadīsiyah, tth.

Amin, Kamaruddin. Menguji Kembali Keakuratan Metode Kritik Hadis. Jakarta: Hikmah, 2009.

Fadhli, Ashabul. "Meramu Ketentuan Hukum Islam Terkait Khitan Perempuan" JURIS (Jurnal Ilmiah Syariah) 14, no. 1 (2016): 59, https://doi.org/10.31958/juris.v14i1.296. 47-61

Ibn Abi Syaibah, Abu Bakar Abdullah bin Muhammad al-Kufi (w.235 H). Al-Kitāb al-Muṣannaf fi al-Aḥ̄āīs wa al-Asār, Jilid 5, Cet. I. Beirut: Dar al-Tāj, 1989.

Ismail, Syuhudi. Metodologi Penelitian Hadis Nabi. Jakarta: Bulan Bintang, 1992.

Jha, Preeti,"Southeast Asia's Hidden Female Genital Mutilation Challenge”. The Diplomat, August,21, 2019. https://thediplomat.com/2019/08/southeast-asiashidden-female-genital-mutilation-challenge/. Diakses pada 17 September 2020

Juned, Daniel. Ilmu Hadis; Paradigma Baru dan Rekonstruksi Ilmu Hadis. Tk: Erlangga, 2010.

Majelis Ulama Indonesia, "Fatwa Majelis Ulama Indonesia no. 9a tahun 2008 tentang Hukum Pelarangan Khitan Terhadap Perempuan”. http://mui.or.id/wpcontent/uploads/files/fatwa/29.-Hukum-Pelarangan-Khitan-TerhadapPerempuan.pdf

Nurasiah, "Khitan Dalam Literatur Hadis Hukum." AHKAM : Jurnal Ilmu Syariah, XV, no.1 (Januari 2019): 93 https://doi.org/10.15408/ajis.v15i1.2851. 81-94.

Oktavira, Bernadetha Aurelia. "Legalitas Sunat Perempuan di Indonesia", Hukum Online.com.19Februari 2020. https://www.hukumonline.com/klinik/detail/ 1t5004324178331/legalitas-sunat-perempuan-di-indonesia/. Diakses pada 17 September 2020

Sakka, Abdul Rahman. "Salat Sunah Enam Rakaat Setelah Magrib: Studi Kritik Hadis." Al-Azhar Islamic Law Review 2, no. 1 (Januasri 2020): 4 https://doi.org/10.37146/ailrev.v2i1.32. 1-13

Sayyidah, Nurma. "Hadis Tentang Hukum Khitan Perempuan (Kajian Sanad Dan Matan)." Jurnal Studi Ilmu-Ilmu Al-Qur'an Dan Hadis 17, no. 1 (Januari 2016): 147 https://doi.org/10.14421/qh.2016.1701-07. 147-160 
Sholeh, M. Asrorun Ni'am, "Fatwa MUI Tentang Khitan Perempuan," AHKAM: $\begin{array}{lllllll}\text { Jurnal Ilmu Syariah XII, } & \text { no. } 2 \text { (Juli 2012): } 44\end{array}$ https://doi.org/10.15408/ajis.v12i2.964. 35-46

Rosyid, Moh. "Hadis Khitan Pada Perempuan: Kajian Kritik Matan Sebagai Upaya Mengakhiri Diskriminasi Gender." Riwayah: Jurnal Studi Hadis 6 no. 1 (2020): 36 https://doi.org/10. 21043/riwayah.v6i1.6869. 19-38

United Nations, "Ending Female Genital Mutilation by 2030", https://www.un.org/en/observances/female-genital-mutilation-day. Diakses pada 4 November 2020

Yusram, Muhammad. "Hukum Meriwayatkan Dan Mengamalkan Hadis Daif Untuk Fadhail Al-A'mal." Nukhbatul 'Ulum 3 no. 1 (2017): 5, https://doi.org/10.36701/nukhbah.v3i1.17. 1-11

Zamzami, Mukhammad. "Perempuan Dan Narasi Kekerasan: Analisis Hukum Dan Medis Sirkumsisi Perempuan.” Asy-Syir'ah: Jurnal Ilmu Syari'ah Dan Hukum 51, no. 1 (Juni 2017): 53, doi.org/10.14421/asy syir'ah.2017.511.53-78

Fadhli, Ashabul. "Meramu Ketentuan Hukum Islam Terkait Khitan Perempuan" JURIS (Jurnal Ilmiah Syariah) 14, no. 1 (2016): 59, https://doi.org/10.31958/juris.v14i1.296. 47-61

Nurasiah, "Khitan Dalam Literatur Hadis Hukum." AHKAM: Jurnal Ilmu Syariah, XV, no.1 (Januari 2019): 93 https://doi.org/10.15408/ajis.v15i1.2851. 81-94 